\title{
Inhibition of Leukocyte-Endothelial Cell Interactions and Inflammation by Peptides from a Bacterial Adhesin which Mimic Coagulation Factor X
}

\author{
Eva Rozdzinski, Jens Sandros, Michiel van der Flier, Alison Young, Barbara Spellerberg, Chandrabali Bhattacharyya, \\ Julie Straub, ${ }^{*}$ Gary Musso, ${ }^{*}$ Scott Putney, ${ }^{*}$ Ruth Starzyk, ${ }^{\star}$ and Elaine Tuomanen \\ Laboratory of Molecular Infectious Diseases, The Rockefeller University, New York 10021; and *Alkermes, Inc., Cambridge, \\ Massachusetts 02139
}

\begin{abstract}
Factor $\mathrm{X}$ (factor ten) of the coagulation cascade binds to the integrin CD11b/CD18 during inflammation, initiating procoagulant activity on the surface of leukocytes (Altieri, D. C., O. R. Etingin, D. S. Fair, T. K. Brunk, J. E. Geltosky, D. P. Hajjar, and T. S. Edgington. 1991. Science [Wash. $D C$ ]. 254:1200-1202). Filamentous hemagglutinin (FHA), an adhesin of Bordetella pertussis also binds to the CD11b/ CD18 integrin (Relman D., E. Tuomanen, S. Falkow, D. T. Golenbock, K. Saukkonen, and S. D. Wright. 1990. Cell. 61:1375-1382). FHA and the CD11b/CD18 binding loops of Factor $X$ share amino acid sequence similarity. FHA peptides similar to Factor $X$ binding loops inhibited ${ }^{125}$ I-Factor $X$ binding to human neutrophils and prolonged clotting time. In addition, ETKEVDG and its Factor $X$ analogue prevented transendothelial migration of leukocytes in vitro and reduced leukocytosis and blood brain barrier disruption in vivo. Interference with leukocyte migration by a coagulation-based peptide suggests a novel strategy for antiinflammatory therapy. (J. Clin. Invest. 1995. 95:1078-1085.) Key words: pertussis $\bullet$ filamentous hemagglutinin $\cdot$ meningitis $\cdot$ integrin $\cdot$ selectin
\end{abstract}

\section{Introduction}

The leukocyte integrin CD11b/CD18 (Mac-1, CR3) plays an important role in leukocyte trafficking during inflammation. Activated $\mathrm{CD} 11 \mathrm{~b} / \mathrm{CD} 18$ promotes the firm adhesion of leukocytes to endothelial cells $(1-3)$. Eukaryotic ligands for CD11b/CD18 are known to include coagulation Factor X, C3bi, and intercellular adhesion molecule-1 (ICAM-1 $)^{1}$ on endothelial cells, and fibrinogen (3-7). This combination of binding specificities has been suggested to provide a point of convergence of the path-

Address correspondence to E. Tuomanen, The Rockefeller University, Box 104, 1230 York Ave., New York, NY 10021. Phone: 212-3278276; FAX: 212-327-7428.

Received for publication 9 September 1994 and in revised form 3 November 1994.

1. Abbreviations used in this paper: CSF, cerebrospinal fluid; FHA, filamentous hemagglutinin; HUVEC, human umbilical vein endothelial cells; ICAM-1, intercellular adhesion molecule-1; TEM, transendothelial migration.

J. Clin. Invest.

(c) The American Society for Clinical Investigation, Inc.

0021-9738/95/03/1078/08 \$2.00

Volume 95, March 1995, 1078-1085 ways for leukocyte adhesion and coagulation which operate during inflammation (8).

Monocytic/myeloid cells stimulated with ADP express activated $\mathrm{CD} 11 \mathrm{~b} / \mathrm{CD} 18$ which binds Factor $\mathrm{X}$ with high affinity in a saturable reaction (5). In a second step, CD11b/CD18-bound Factor $\mathrm{X}$ is converted to the proteolytically active Factor $\mathrm{Xa}$, thereby initiating the coagulation cascade on the surface of monocytes and neutrophils (9). Binding of Factor X to CD11b/ CD18 has been demonstrated to be mediated by three surface loops: GYDTKQED (residues 366-373), IDRSMKTRG (422-430), and LYQAKRFKV (238-246) as evidenced by the ability of peptides representing these three binding regions to block radiolabeled Factor $\mathrm{X}$ binding to the monocytic cell line, THP-1 (8). These peptides also inhibit the generation of Factor Xa procoagulant activity.

Filamentous hemagglutinin (FHA) of Bordetella pertussis is a $220-\mathrm{kD}$ nonfimbrial membrane protein that binds to cilia and macrophages of the human respiratory tract during whooping cough $(10,11)$. Of the several interactions FHA exhibits with macrophages, the ability to bind to the integrin CD11b/CD18 has received the most attention. To enter phagocytes without an oxidative burst, many prokaryotes bind to carbohydrate substituents on the integrin CD11b/CD18 or become coated with C3bi (12). In contrast, $B$. pertussis binds directly to the integrin in a protein-protein interaction mediated by FHA. This direct interaction has been demonstrated to occur with purified FHA and integrin (13). Previously, the region of FHA suggested to participate in this direct binding was a domain containing an Arg-Gly-Asp (RGD) sequence (14). More recently, it has been recognized that, although the RGD in FHA clearly promotes binding of FHA or bacteria to the integrin presented on cells, binding of purified FHA to purified integrin is not influenced by RGD peptides (13). Non-RGD-mediated interactions may therefore explain the direct binding between FHA and CD11b/CD18. While delineation of the mechanism of this interaction is of obvious importance to understanding the pathogenesis of whooping cough, it is also of potential value as a unique probe into the biology of the CD11b/ CD18 adhesion molecule.

Here we present evidence that regions of FHA mimic motifs of Factor $\mathrm{X}$ of the coagulation cascade, a natural ligand of $\mathrm{CD} 1 \mathrm{~b} / \mathrm{CD} 18$. In addition to preventing the generation of procoagulant activity, this interaction also appears to interfere with adherence and transendothelial migration of leukocytes. Using a rabbit model of meningitis, we also demonstrate that peptides derived from Factor X and FHA inhibit CD18-dependent leukocyte migration in vivo and protect against blood brain barrier injury.

\section{Methods}

Peptides. Purified FHA of B. pertussis was obtained from List Biologicals (Campbell, CA). Peptides derived from FHA and Factor X were 
Table I. Inhibition of Transendothelial Migration (TEM) of Neutrophils by FHA and Factor X-and FHA-derived Peptides

\begin{tabular}{lcc}
\hline \multicolumn{1}{c}{ Peptide } & Amino acid sequence & $\begin{array}{c}\text { Percent inhibition } \\
\text { of TEM }\end{array}$ \\
\hline Native FHA & & $82 \pm 1$ \\
Factor X I & ${ }^{238}\left(\right.$ G) LYQAKRFKV $(G){ }^{246}$ & $10 \pm 6$ \\
FHA Ia & ${ }^{1979}$ LGYQAK $^{1984}$ & $23 \pm 5$ \\
FHA Ib & ${ }^{2523}$ GLIQGRSVKVD $^{2533}$ & $7 \pm 10$ \\
Factor X II & ${ }^{366}{\text { GYDTKQED(G })^{373}}^{273}$ & $14 \pm 9$ \\
FHA II & ${ }^{2062}$ ETKEVDG $^{2068}$ & $21 \pm 10$ \\
Acetyl/amide FHA II & & $61 \pm 6$ \\
Scrambled FHA II & DEETVK & $4 \pm 5$ \\
Factor X III & ${ }^{422}$ IDRSMKTRG $^{430}$ & $5 \pm 7$ \\
FHA III & ${ }^{32}$ GRTRG $^{36}$ & $5 \pm 6$ \\
\hline
\end{tabular}

Peptides derived from Factor $\mathrm{X}$ were synthesized with glycine added to the termini in some cases $(\mathrm{G})$ to match the peptides originally described in Altieri et al. (8). Residues, identical to Factor X peptides, are highlighted in bold. Fluorescein-labeled neutrophils were incubated with $10 \mu \mathrm{M}$ of peptides or $0.1 \mu \mathrm{M}$ of native FHA in M199 and, without washing, were added to HUVEC monolayers. TEM was terminated after $1 \mathrm{~h}$. In control wells containing M199 alone, $51 \pm 10 \%$ of neutrophils transmigrated. Percent inhibition by FHA or peptides was calculated in reference to control wells set at $100 \%$ TEM. mAb W6/32 $(25 \mu \mathrm{g} / \mathrm{ml}$, negative control) did not inhibit TEM significantly $(6 \pm 6 \%)$, whereas $\mathrm{mAb}$ IB4 $(25 \mu \mathrm{g} / \mathrm{ml}$, positive control) inhibited by $73 \pm 14 \%(n=6)$. Values represent mean \pm standard deviation of at least 3 experiments with 6 wells/peptide. Values of $>15 \%$ are significantly different from control at $P<0.05$ ( $t$ test).

synthesized by The Rockefeller University Protein Sequencing Facility or Alkermes, Inc. using FMOC chemistry and purified by HPLC (Table I).

Binding of Factor X to neutrophils. Human Factor X (Sigma Chemical Co. or Hematologic Technologies Inc., St. Louis, MO) was labeled with ${ }^{125}$ I using Iodogen (Pierce Chemical Co., Rockford, IL) (5). Human neutrophils were isolated from heparinized blood according to the manufacturer's specification using neutrophil isolation medium (Cardinal Associates, Santa Fe, NM) and washed three times with $5 \mathrm{mM}$

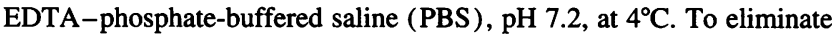
platelet contamination, neutrophils were incubated with autologous serum containing $5 \mathrm{mM}$ EDTA for $30 \mathrm{~min}$ at $37^{\circ} \mathrm{C}$, washed three times with ice-cold PBS, pH 7.2, and resuspended in RPMI 1640 tissue culture medium (Whittaker M. A. Bioproducts, Walkersville, MD) at $4^{\circ} \mathrm{C}$. Binding of ${ }^{125} \mathrm{I}$-Factor $\mathrm{X}$ to neutrophils was measured based on a method described by Altieri et al. (8). Briefly, $200 \mu$ l of neutrophils $\left(1.5 \times 10^{7} /\right.$ $\mathrm{ml}$ ) was supplemented with $17.5 \mu \mathrm{l}$ of $50 \mathrm{mM} \mathrm{CaCl}_{2}$, stimulated with $3.5 \mu \mathrm{l}$ of $100 \mu \mathrm{M} \mathrm{NH}$-formyl-Met-Leu-Phe (Sigma Chemical Co.), and mixed with $30 \mu \mathrm{l}$ of $10.3 \mu \mathrm{g} / \mathrm{ml}{ }^{125} \mathrm{I}$-Factor X and $100 \mu \mathrm{l}$ of 1.75 $\mathrm{mM}$ peptide. Buffer alone and a peptide of scrambled sequence served as controls in each of the three experiments. After incubation for 20 $\mathrm{min}$ at room temperature, neutrophil-bound ${ }^{125} \mathrm{I}$-Factor $\mathrm{X}$ was separated from unbound ${ }^{125} \mathrm{I}$-Factor $\mathrm{X}$ by centrifugation of $300-\mu \mathrm{l}$ aliquots through $50 \mu \mathrm{l}$ of a mixture of Hi phenyl silicone oil DC 550 and methyl silicone oil DC 200 5:1 (Nye Inc. Specialty Lubricants, New Bedford, MA) at $12,000 \mathrm{~g}$ for $2 \mathrm{~min}$. Aliquots of the supernatant (cell free ${ }^{125} \mathrm{I}$-Factor $\mathrm{X}$ ) and the cell pellet (cell bound ${ }^{125} \mathrm{I}$-Factor $\mathrm{X}$ ) were counted in a gamma counter. Nonspecific binding $(\sim 50,000 \mathrm{cpm})$ was determined by adding a 100 -fold excess of unlabeled Factor $\mathrm{X}$, and subtracted from total radioactivity $(\sim 500,000 \mathrm{cpm}$ for controls $)$.
Generation of Factor Xa by monocytes. Factor Xa generation was determined by a modification of the method of Miletich et al. (14a). THP-1 cells $3 \times 10^{7} / \mathrm{ml}$; American Type Culture Collection, Rockville, MD) resuspended in RPMI 1640 were incubated with $100 \mu \mathrm{M}$ ADP (Sigma Chemical Co.), $2.5 \mathrm{mM} \mathrm{CaCl}_{2}, 5 \mu \mathrm{g} / \mathrm{ml}$ Factor X, and $0.5 \mathrm{mM}$ peptides at room temperature. After $20 \mathrm{~min}, 100 \mu \mathrm{l}$ of the reaction mixture was transferred to $37^{\circ} \mathrm{C}$ and supplemented with $100 \mu \mathrm{l}$ of bovine Factor VII- and Factor X-deficient plasma (Sigma Chemical Co.). Coagulation was initiated by adding $100 \mu \mathrm{l}$ of $25 \mathrm{mM} \mathrm{CaCl}_{2}$ and the clotting time was determined. Factor Xa procoagulant activity (nanograms per milliliter) was calculated by means of a standard curve constructed by serial concentrations of Factor Xa (Hematologic Technologies Inc.) from 10 to $250 \mathrm{ng} / \mathrm{ml}$.

Adherence of neutrophils to cultured endothelial cells. Human umbilical vein endothelial cells (HUVEC) (first passage; Clonetics Corp., San Diego, CA) were subcultured at confluence into Terasaki tissue culture wells. After $24 \mathrm{~h}$, confluent monolayers were used for adherence assays (3). Monolayers were stimulated with $10 \mathrm{ng} / \mathrm{ml}$ TNF alpha (Boehringer Mannheim, Indianapolis, IN) at $37^{\circ} \mathrm{C}$ for $4 \mathrm{~h} .30 \mu \mathrm{l}$ of human neutrophils $\left(10^{6} / \mathrm{ml}\right)$ was labeled with fluorescein $(3)$, and preincubated for $15 \mathrm{~min}$ at $37^{\circ} \mathrm{C}$ with $20 \mu \mathrm{l}$ of peptides (final concentration $0.5 \mathrm{mM}$ in HAP) or HAP (PBS containing $0.5 \mathrm{mg} / \mathrm{ml}$ human serum albumin, $3 \mathrm{mM}$ glucose, and $0.3 \mathrm{U} / \mathrm{ml}$ aprotinin) as a control buffer. FHA was used at $0.1 \mu \mathrm{M}$ (the upper limit of solubility). Neutrophils were allowed to adhere to the monolayer for $15 \mathrm{~min}$ at $37^{\circ} \mathrm{C}$, and unbound cells were removed by submersion of the plate in PBS buffer. The number of adherent neutrophils was counted in a $40 \times$ microscope field and expressed as a percentage of adherence in control wells with neutrophils treated with HAP buffer alone. The mAb IB4 against CD18 (Merck Inc., Rahway, NJ) served as a positive control.

Transendothelial migration of neutrophils. Transendothelial migration of neutrophils was studied based on a method described by Muller and Weigl in which leukocytes that have traversed and lie underneath the monolayer are counted (15). Briefly, human neutrophils suspended in ice-cold Hanks' balanced salt solution (HBSS) containing $\mathrm{Ca}$ and $\mathrm{Mg}$ (Sigma Chemical Co.) were fluoresceinated by adding $3.3 \mu \mathrm{l} / \mathrm{ml} \mathrm{5-}$ (and-6)-carboxyfluorescein diacetate, succinimidyl ester (CFSE; Molecular Probes, Inc., Eugene, OR). After incubation for $30 \mathrm{~min}$ on ice, neutrophils were washed twice in cold HBSS with $\mathrm{Ca}$ and $\mathrm{Mg}$ and resuspended in cold Medium 199 (M199; Sigma Chemical Co.) to a final concentration of $10^{6} / \mathrm{ml}$. HUVEC were subcultured at confluence into 96-well tissue culture plates (Becton Dickinson Labware, Lincoln Park, NJ) that were coated with hydrated collagen gel (Vitrogen; Collagen Corp., Palo Alto, CA) and fibronectin. Endothelial cells were stimulated with $10 \mathrm{ng} / \mathrm{ml} \mathrm{TNF}$-alpha for $4 \mathrm{~h}$ and washed three times with warm M199. Neutrophils $\left(10^{6} / \mathrm{ml}\right)$ were preincubated with $0.01 \mathrm{mM}$ of peptides for $5 \mathrm{~min}$ on ice before they were added in 100- $\mu$ l aliquots to the endothelial cells. For positive control, neutrophils were preincubated with $25 \mu \mathrm{g} / \mathrm{ml}$ anti-CD18 mAb IB4. For negative control, neutrophils were treated with $25 \mu \mathrm{g} / \mathrm{ml} \mathrm{mAb}$ W6/32 against HLA class I antigen (Dako Corp., Carpinteria, CA). The cells were incubated for 1 $h$ at $37^{\circ} \mathrm{C}, 5 \% \mathrm{CO}_{2}$. To terminate transmigration, the supernatant fluid was aspirated and the wells were filled with warm 1 mM EGTA (Sigma Chemical Co.) in HBSS without $\mathrm{Ca}$ and $\mathrm{Mg}$. The plates were covered with plate sealer (Dynatech, Alexandria, VA) and centrifuged in an inverted position at $250 \mathrm{~g}$ for $3 \mathrm{~min}$ at room temperature. To remove nontransmigrated neutrophils, monolayers were washed twice with 200 $\mu \mathrm{l}$ of warm Hanks' solution without $\mathrm{Ca}$ and $\mathrm{Mg}$. Fluorescence was quantitated using a fluorescence counter (Cytofluor ${ }^{\mathrm{TM}}$ 2300; Millipore Corp., Bedford, MA). The percentage of transmigrated neutrophils was determined by comparing the fluorescence of test wells to collagen- and fibronectin-coated wells without endothelial cells. Fluorescence counts were corrected for contamination of the neutrophil preparation with lymphocytes $(<10 \%)$ which do not transmigrate; contamination with monocytes as assessed by light microscopy was $<5 \%$. Percent inhibition of transendothelial migration of neutrophils was calculated by compar- 
ing the number of transmigrated cells in wells containing neutrophils treated with peptide to neutrophils treated with M199 alone.

Rabbit model for meningitis. The rabbit model was performed according to an established protocol $(16,17)$. Specific pathogen-free, New Zealand White rabbits ( $2 \mathrm{~kg}$; Hare Marland, Nutley, NJ) were anesthetized with Valium $(2.5 \mathrm{mg} / \mathrm{kg}$, subcutaneously; HoffmanLaRoche, Nutley, NJ), ketamine ( $35 \mathrm{mg} / \mathrm{kg}$, intramuscularly; Aveco Co., Fort Dodge, IA), and xylazine ( $5 \mathrm{mg} / \mathrm{kg}$, intramuscularly; Miles Laboratories, Shawnee, KS ), and a helmet of dental acrylic was affixed to the calvarium. $24 \mathrm{~h}$ later, the rabbits were anesthetized with ethyl carbamate $(1.75 \mathrm{~g} / \mathrm{kg}$; Aldrich Chemical Co., Milwaukee, WI) and pentobarbital ( $15 \mathrm{mg} / \mathrm{kg}$; Abbott Laboratories, Abbott Park, IL) and placed in a stereotaxic frame. A spinal needle was introduced into the cisterna magna, and $300 \mu \mathrm{l}$ of cerebrospinal fluid (CSF) was withdrawn. The animals were challenged intracisternally with $10^{8}$ heat-killed, unencapsulated pneumococcus strain R6 introduced in $200 \mu \mathrm{l}$ of saline (time $0) .1 \mathrm{~h}$ later animals were treated with peptides dissolved in $1 \mathrm{ml}$ of saline by intravenous injection into the right marginal ear vein. Samples of CSF were withdrawn at hourly intervals after pneumococcal inoculation, and leukocyte density was measured using a counter (Coulter Corp., Hialeah, FL). CSF samples were centrifuged at $10,000 \mathrm{~g}$ for 5 min, and the supernatant was stored at $-70^{\circ} \mathrm{C}$ until assayed for protein concentration using the bicinchoninic acid method (BCA kit; Pierce Chemical Co.) and for lactate concentration (lactate detection kit; Sigma Chemical Co.). Differences between treatments were determined by one-way ANOVA.

Determination of stability of peptides in rabbit plasma. Rabbit blood was heparinized and centrifuged to yield plasma. Peptides were dissolved in PBS ( $120 \mathrm{mM} \mathrm{NaCl}, 2.7 \mathrm{mM} \mathrm{KCl}, 1.9 \mathrm{mM} \mathrm{NaH}_{2} \mathrm{PO}_{4}$, and $8.1 \mathrm{mM} \mathrm{Na}_{2} \mathrm{HPO}_{4}$ ) at a concentration of $62.5 \mu \mathrm{M}$. The peptides were mixed with an equal volume of plasma, and the samples were analyzed by HPLC at $0,2,4,6,8,24$, and $48 \mathrm{~h}$. Analysis was performed on a Hewlett-Packard (Palo Alto, CA) 1090 HPLC using a protein and peptide column (C18; VYDAC, Hesperia, CA ) $(4.6 \mathrm{~mm} \times 250 \mathrm{~mm}, 5$ $\mu \mathrm{m}$ particle size) equilibrated with $0.1 \mathrm{M}$ sodium perchlorate $/ 0.1 \%$ phosphoric acid (85\%) in water, at $\mathrm{pH} 2.5$, and eluted with acetonitrile in a gradient from 0 to $40 \%$ over $40 \mathrm{~min}$ (flow $1 \mathrm{ml} / \mathrm{min}$; monitored at $210 \mathrm{~nm}$ ).

\section{Results}

Sequence similarity between FHA and the CD11b/CD18 binding sites of Factor $X$. The amino acid sequence of FHA was compared with that of the three regions of human coagulation Factor $\mathrm{X}$ that are known to bind to the leukocyte integrin CD11b/CD18 (8). Sequence similarity ( $40-70 \%$ identity) was found between amino acid residues 238-246, 366-373, and 422-430 of Factor X (according to Fung et al. [18]) and FHA residues 1979-1984, 2062-2068, 32-36, and 2523-2533 (according to Relman et al. [19]) (Table I).

FHA peptides block Factor $X$ binding to leukocytes. In accordance with previous observations (8), three peptides from Factor $\mathrm{X}$ inhibited ${ }^{125} \mathrm{I}$-Factor $\mathrm{X}$ binding to leukocytes by 50 90\% (Fig. 1 A, stippled bars). Native FHA and FHA peptide II showed strong inhibition of ${ }^{125} \mathrm{I}$-Factor $\mathrm{X}$ binding to neutrophils of $70 \pm 4$ and $87 \pm 8 \%$, respectively (Fig. 1 A, shaded bars). The other FHA peptides also demonstrated significant inhibition, but to a lesser extent than the corresponding Factor $\mathrm{X}$ peptides. Native FHA, FHA peptide II, and the corresponding Factor $\mathrm{X}$ peptide II inhibited ${ }^{125} \mathrm{I}$-Factor $\mathrm{X}$ binding in a concentration-dependent manner (Fig. $1 B$ ).

FHA peptides inhibit Factor Xa procoagulant activity on monocytes. Binding of Factor $\mathrm{X}$ to leukocytes is followed by conversion to Factor $\mathrm{Xa}$ and initiation of coagulation. Factor
A.

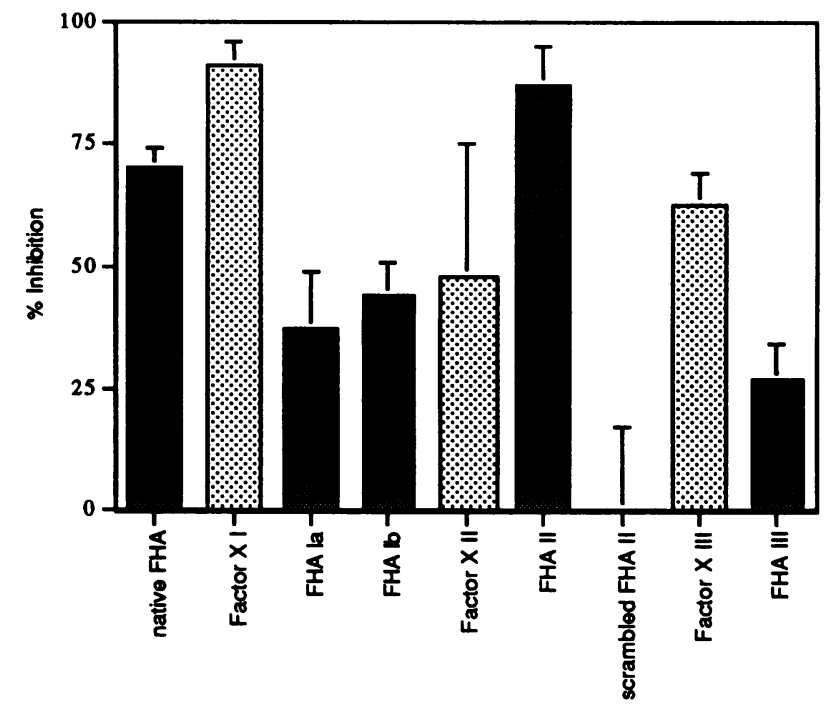

B

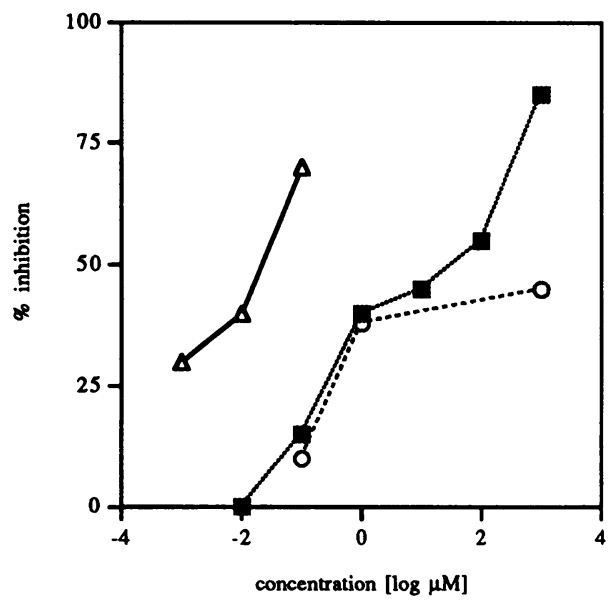

Figure 1. Inhibition of ${ }^{125} \mathrm{I}$-Factor $\mathrm{X}$ binding to neutrophils by FHA, FHA-, or Factor X-peptides. Stimulated neutrophils $\left(3 \times 10^{6}\right)$ were mixed with $15 \mathrm{nM}^{125} \mathrm{I}$-Factor $\mathrm{X}$ and peptides (as designated in Table I) or native FHA. Neutrophil-bound ${ }^{125}$ I-Factor $X$ was separated from unlabeled Factor $\mathrm{X}$ by centrifugation through silicone oil. $A$, peptides $500 \mu \mathrm{M}$, native FHA $0.3 \mu \mathrm{M}$. Values represent the mean \pm standard deviation of triplicate experiments. B, FHA peptide II (filled square), Factor X peptide II (open circle), and FHA (open triangle). Values are representative of triplicate experiments (standard deviations $<15 \%)$.

Xa generation on activated THP-1 cells in the absence of peptide or in the presence of a control peptide (a scrambled FHA II analogue) was $>110 \mathrm{ng} / \mathrm{ml}$ (Table II). The concentration of Factor Xa correlated inversely with the clotting time. Factor X peptides I and II decreased Factor Xa production $(<40 \mathrm{ng} /$ $\mathrm{ml}$ ), thereby significantly prolonging clotting time (Table II). FHA peptides Ia, Ib, and III also significantly reduced Factor $\mathrm{Xa}$ production by $50-70 \%$. Although FHA peptide II reduced the generation of Factor Xa procoagulant activity by only $25 \%$, the $\mathrm{NH}_{2}$-terminal acetylated and $\mathrm{COOH}$-terminal amidated form of this peptide significantly enhanced this effect.

FHA peptides inhibit adherence and transendothelial mi- 
Table II. Inhibition of Generation of Factor Xa by Peptides Derived from Factor $X$ or FHA

\begin{tabular}{lcc}
\multicolumn{1}{c}{ Peptide } & Clotting time & Factor Xa \\
\hline & $s$ & $n g / m l$ \\
Factor X I & $37 \pm 4$ & $37.8^{*}$ \\
FHA Ia & $34 \pm 1$ & $57.4^{*}$ \\
FHA Ib & $38 \pm 7$ & $31.3^{*}$ \\
Factor X II & $55 \pm 4$ & $<10^{*}$ \\
FHA II & $30 \pm 5$ & 86.0 \\
Acetyl/amide FHA II & $40 \pm 3$ & $28.5^{*}$ \\
Factor X III & $26 \pm 2$ & 107.5 \\
FHA III & $36 \pm 3$ & $43.4^{*}$ \\
Scrambled FHA II & $23 \pm 1$ & 165.0 \\
HAP buffer & $26 \pm 2$ & 112.2 \\
Leupeptin $(25 \mu \mathrm{g} / \mathrm{ml})$ & $63 \pm 4$ & $<10^{*}$ \\
\hline
\end{tabular}

THP-1 cells $\left(3 \times 10^{7} / \mathrm{ml}\right)$ were incubated with $100 \mu \mathrm{M}$ ADP, $2.5 \mathrm{mM}$ $\mathrm{CaCl}_{2}, 5 \mu \mathrm{g} / \mathrm{ml}$ Factor $\mathrm{X}$, and $0.5 \mathrm{mM}$ peptides at room temperature. After $20 \mathrm{~min}$, aliquots of the reaction mixture were supplemented with Factor VII- and Factor X-deficient plasma and recalcified with $25 \mathrm{mM}$ $\mathrm{CaCl}_{2}$. Factor Xa coagulant activity was calculated by using a standard curve constructed by serial dilutions of Factor Xa. Values represent mean \pm standard deviation of at least three experiments. * Statistically significant difference as compared with scrambled FHA peptide II at $P$ $<0.05$ ( $t$ test).

gration of leukocytes. FHA peptides were tested for their ability to interfere with neutrophil adherence to stimulated HUVEC (Fig. $2 A)$. The anti-CD18 mAb IB4 $(50 \mu \mathrm{g} / \mathrm{ml})$ inhibited neutrophil adherence to HUVECs by $38 \pm 10 \%$ (not shown). Native FHA $(25 \mu \mathrm{g} / \mathrm{ml}=0.1 \mu \mathrm{M})$ reduced neutrophil binding by $51 \pm 8 \%$. The FHA peptide Ia was significantly more active than the Factor X peptide I, whereas the FHA peptide II and Factor X peptide II demonstrated similar activities. The scrambled FHA II peptide did not interfere with neutrophil binding. As shown in Fig. 2 B, native FHA, Factor X-, and FHA-peptides were found to inhibit neutrophil adherence in a concentrationdependent manner.

Since CD18-dependent leukocyte adherence to activated endothelia is a prerequisite to transendothelial migration, the FHA and Factor $\mathrm{X}$ peptides were tested for the ability to prevent neutrophil transmigration in vitro (Table I). mAb IB4 $(25 \mu \mathrm{g} /$ $\mathrm{ml}$ ) reduced transendothelial migration by $73 \pm 14 \%$ (not shown ). In concordance with the results in the adherence assay, FHA peptides Ia and II showed consistently detectable activity, although the magnitude of the effect was low $(\sim 20 \%)$. (Table I). This activity was greatly augmented by the acetyl/amide modification of FHA II, leading to an inhibition of $61 \pm 6 \%$. From this and the neutrophil adherence analyses, FHA peptides Ia and II were identified as candidates for more extensive testing.

Several experiments were done to investigate the mechanism by which these peptides inhibited adherence and transendothelial migration of neutrophils. First, we sought to determine whether they could enhance the ability of mAb IB4, a strong inhibitor of neutrophil transendothelial migration, to block neutrophil adherence to endothelial cells. Table III shows that the
A

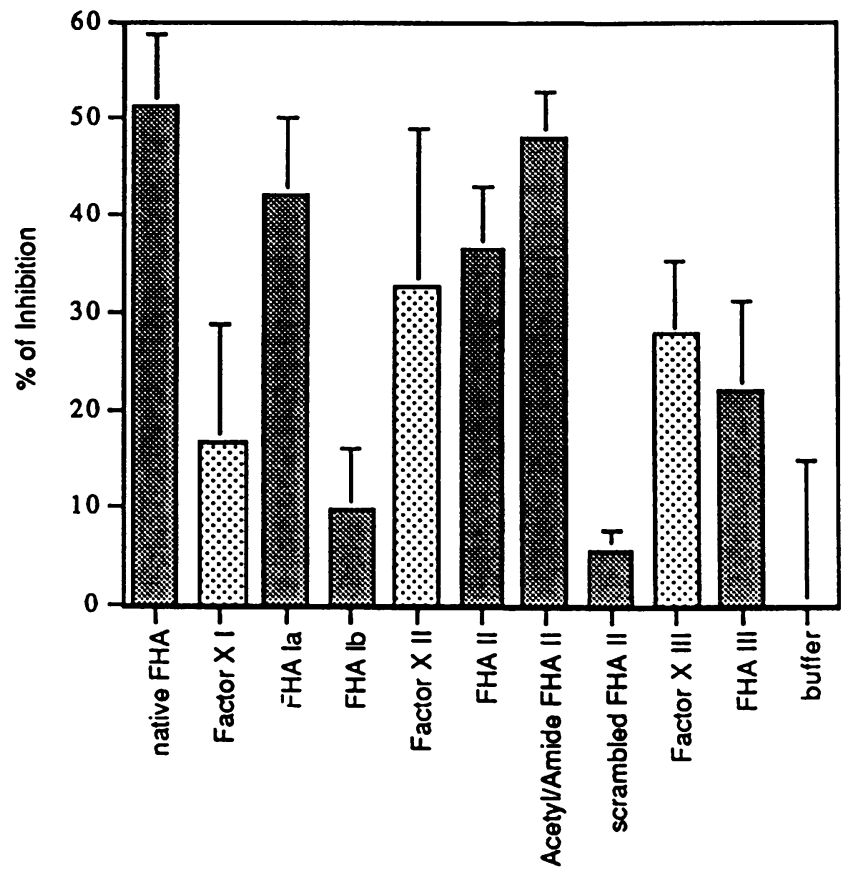

B

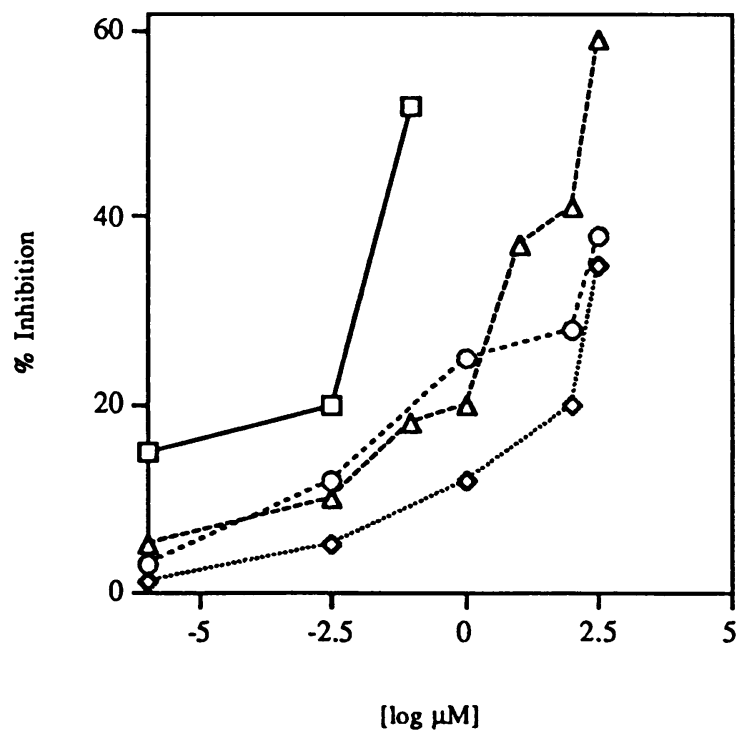

Figure 2. Inhibition of neutrophil adherence to activated endothelial cells by FHA, Factor X-, and FHA-derived peptides. Fluoresceinated human neutrophils were incubated with peptides (designated as in Table I) and then allowed to adhere to activated HUVEC monolayers. After washing, the number of adherent neutrophils was counted in a $40 \times$ microscope field and expressed as a percentage of adherence in control wells with neutrophils treated with buffer alone. A, peptides $500 \mu \mathrm{M}$, native FHA $0.1 \mu \mathrm{M}$; values represent the mean \pm standard deviation of 4 experiments with 5 wells/peptide. B, FHA peptide II (circle), acetyl/ amide peptide II (triangle), and Factor X peptide II (diamond) at $10^{-6}$ $\mu \mathrm{M}$ to $500 \mu \mathrm{M}$; native FHA at $10^{-6}$ to $10^{-1} \mu \mathrm{M}$ (square). Values represent the mean of 3 experiments with 5 wells/peptide (standard deviations $<15 \%$ ). 
Table III. Ability of Antibodies to Augment the Inhibition of Neutrophil Adherence Achieved by FHA Peptides

\begin{tabular}{lcc}
\hline & \multicolumn{2}{c}{ Antibody } \\
\cline { 2 - 3 } Peptide & None & IB4 \\
\hline None & $100^{*}$ & $39 \pm 8$ \\
FHA Ia & $63 \pm 12$ & $20 \pm 7^{\ddagger}$ \\
FHA II & $40 \pm 23$ & $11 \pm 6^{\ddagger}$ \\
\end{tabular}

* Values are percentages \pm standard deviation of control binding in at least four experiments. In control wells, $228 \pm 46$ neutrophils were adherent per $40 \times$ field. Peptides were added at $5 \mu \mathrm{g} / \mathrm{ml}$. mAb IB4 is directed against CD18 and was added to leukocytes at $10 \mu \mathrm{g} / \mathrm{ml}$ for $10 \mathrm{~min}$ before the assay. ${ }^{\ddagger}$ Statistically significant difference compared with antibody or peptide alone.

combination of IB4 and FHA Ia and II peptides showed greater inhibition of neutrophil adherence than either agent alone, indicating that the adhesion-inhibiting effects were additive. Maximum inhibition with antibody or peptide alone was $\sim 40-60 \%$ of control values. Preincubation of neutrophils with FHA peptides Ia or II together with $10 \mu \mathrm{g} / \mathrm{ml}$ anti-CD18 mAb IB4 resulted in an additive reduction of neutrophil adherence to $\geq 80 \%$. In addition, IB4 only modestly reduced ${ }^{125} \mathrm{I}$-Factor $\mathrm{X}$ binding to leukocytes. The amount of Factor $\mathrm{X}$ bound in the presence of $50 \mu \mathrm{g} / \mathrm{ml} \mathrm{mAb}$ IB 4 was $81 \pm 6 \%$ of that bound in the absence of antibody, yet $25 \mu \mathrm{g} / \mathrm{ml}$ of mAb IB4 strongly inhibited leukocyte transmigration (73\% inhibition, Table I). Taken together, these results indicate that the peptides are acting at a site independent of that bound by IB4.

We also investigated the possibility that the proteolytic activity associated with the $\mathrm{X}$ to $\mathrm{Xa}$ conversion might promote leukocyte transmigration. This hypothesis would predict a correlation between inhibition of the generation of Factor Xa (i.e., an anticoagulant effect) and inhibition of leukocyte transmigration. The discordance of the anticoagulant effects of FHA peptides Ia, Ib, and III and the poor antimigration effects (compare Tables I and II) argues against this hypothesis. Similarly, the protease inhibitor leupeptin inhibited generation of Factor Xa ( $>90 \%$ inhibition, Table II) but failed to block leukocyte transmigration ( $6 \pm 6 \%$ inhibition as performed according to Table I at $25 \mu \mathrm{g} / \mathrm{ml}$ ). This result suggests that proteolytic activity is not correlated with transmigration and that the peptides are unlikely to exert their effect on neutrophil migration by inhibiting proteolysis associated with coagulation factors.

The antiinflammatory effect of FHA peptides with Factor $X$ homology in vivo. To determine if the ability to block neutrophil attachment and transmigration in vitro predicted antiinflammatory activity in vivo, several peptides were tested in an animal model of pneumococcal meningitis for the capacity to prevent leukocyte extravasation from the bloodstream into the CSF. Native FHA and FHA- and Factor X-derived peptides were injected intravenously $1 \mathrm{~h}$ after intracisternal challenge with pneumococci. Fig. 3 depicts the leukocyte response over $7 \mathrm{~h}$. Native FHA, FHA peptides I and II, and Factor X peptide II resulted in a significant reduction of CSF leukocytosis of $>60 \%$ $(P<0.05)$. The scrambled FHA peptide II was ineffective $(P$ $>0.5)$.

To determine the stability of the FHA II peptide, the unmod-
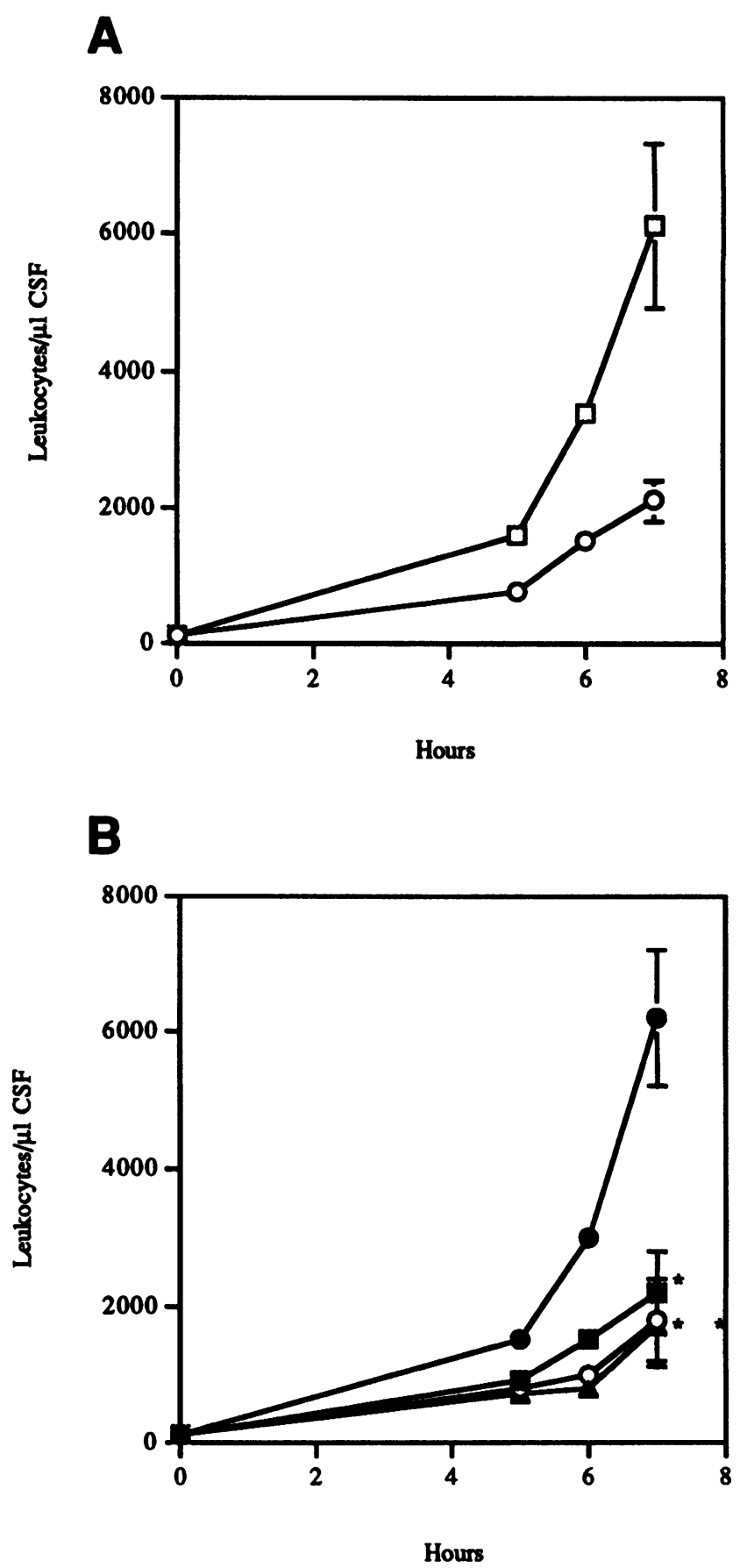

Figure 3. Antiinflammatory activity of FHA, and FHA-, and Factor Xderived peptides in experimental bacterial meningitis. Meningeal inflammation was induced in rabbits by intracisternal challenge with $10^{8}$ heat-killed pneumococci. $1 \mathrm{~h}$ later, animals received an intravenous injection of $10 \mathrm{nmol}$ of peptide in $1 \mathrm{ml}(n \geq 4), 25 \mu \mathrm{g}$ FHA $(n=5)$, or PBS $(n=10)$. Leukocyte density in CSF was determined at 5,6 , and $7 \mathrm{~h}$ after pneumococcal challenge. $A$, FHA $\bigcirc$; PBS $\square . B$, FHA peptide I O; FHA peptide II $₫$; Factor X peptide II $\Delta$; scrambled FHA peptide II ๑. * Statistically significant difference from control $(P<0.01)$.

ified or the acetylated-amidated peptide was incubated in $50 \%$ rabbit plasma at $37^{\circ} \mathrm{C}$. The concentration of unprotected FHA peptide II was decreased by half in $4-6 \mathrm{~h}$, whereas the concentration of the acetylated-amidated derivative remained un- 


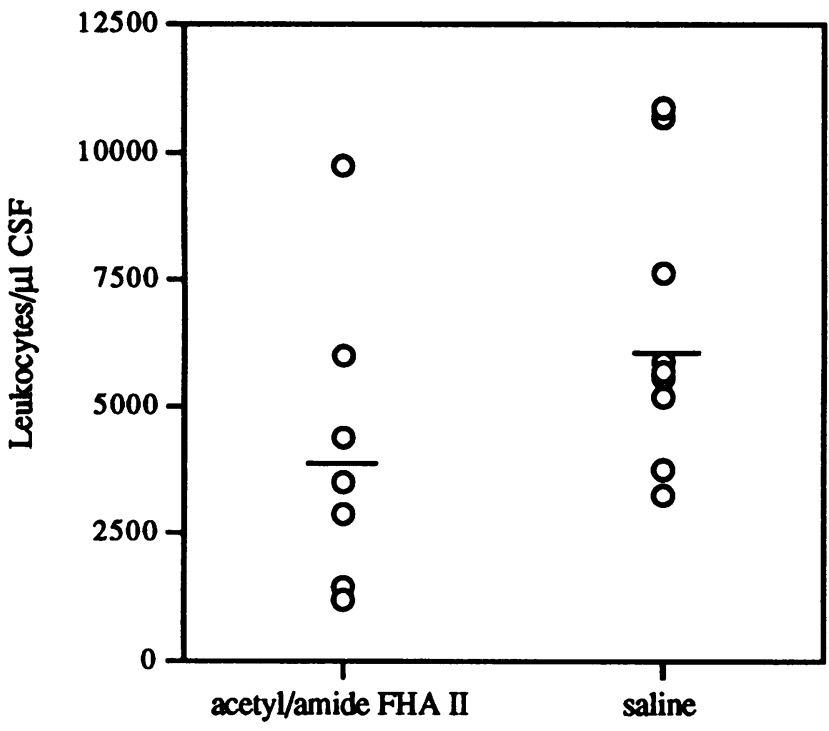

Figure 4. Ability of acetyl/amide FHA II peptide to inhibit accumulation of leukocytes in CSF. 2 groups of 10 animals were challenged with pneumococci as in Fig. 3. $1 \mathrm{~h}$ later, animals received an intravenous injection of $10 \mathrm{nmol}$ of peptide $(8.2 \mu \mathrm{g})$ or PBS. Leukocyte density in CSF was determined at $6 \mathrm{~h}$ after pneumococcal challenge. Mean values as indicated by the bars are statistically significantly different at $P$ $=0.0015$ by ANOVA.

changed over $48 \mathrm{~h}$. Rabbits $(n=10)$ were treated with $10 \mathrm{nmol}$ of the acetyl-amide-FHA II. Control animals $(n=10)$ exhibited a mean of $6,480 \pm 684$ leukocytes/ $\mu \mathrm{l} \mathrm{CSF}$ at $6 \mathrm{~h}$ after pneumococcal challenge. In contrast, animals receiving the acetylamide-FHA II demonstrated a significant reduction of leukocyte migration into the CSF to $3,011 \pm 684$ cells $/ \mu \mathrm{l}(P=0.0015$, ANOVA) (Fig. 4).

Protection against blood brain barrier permeability afforded by FHA peptides. Loss of barrier function of the cerebral capillary endothelium during inflammation is reflected by an influx of serum proteins into the CSF, and impaired cerebral metabolism has been shown to correlate with increased lactate concentrations in CSF (17). An effective antiinflammatory agent should ameliorate both of these parameters of injury. To examine if the ability of the peptides to decrease leukocyte transmigration correlated with improvements of these measures of cerebral injury, CSF protein and lactate concentrations were measured in peptide-treated and control animals (Table IV). FHA peptide II and its acetyl-amide derivative significantly reduced protein influx into the CSF and generation of lactate $(P<0.02)$. FHA peptide I and Factor $\mathrm{X}$ peptide II did not cause a significant reduction in protein influx, a finding indicating a greater potency of FHA peptide II.

\section{Discussion}

The binding of Factor $\mathrm{X}$ to the integrin $\mathrm{CD} 11 \mathrm{~b} / \mathrm{CD} 18$ on the surface of ADP-activated monocytic cells initiates cleavage of the zymogen Factor $\mathrm{X}$ to Factor $\mathrm{Xa}$ and thereby activates the coagulation cascade in the microenvironment of an inflamed tissue (9). The binding sites on Factor $X$ have been mapped to three spatially separate regions which contact the alpha subunit
Table IV. Effect of Peptides on Blood Brain Barrier Permeability and Lactate Metabolism during Meningeal Inflammation

\begin{tabular}{lll}
\hline \multicolumn{1}{c}{ Peptide } & Lactate & Protein \\
\hline & $m g / l 00 \mathrm{ml}$ & $\mathrm{mg} / \mathrm{ml}$ CSF \\
Saline control & $38.7 \pm 4.8$ & $2.1 \pm 0.4$ \\
FHA & $25.0 \pm 5.3^{*}$ & $1.3 \pm 0.3^{*}$ \\
FHA I & $36.0 \pm 6.7$ & $1.8 \pm 0.4$ \\
FHA II & $25.5 \pm 4.1^{*}$ & $1.4 \pm 0.6^{*}$ \\
Acetyl/amide FHA II & $24.3 \pm 3.2^{*}$ & $1.2 \pm 0.6^{*}$ \\
Factor X II & $37.6 \pm 6.9$ & $1.6 \pm 0.7$ \\
Scrambled FHA II & $40.7 \pm 5.8$ & $1.9 \pm 0.3$ \\
& & \\
\hline
\end{tabular}

Mean values for CSF lactate and protein at time 0 were $18.6 \pm 5.8$ and $0.8 \pm 0.2$, respectively. Animals received FHA $(0.1 \mathrm{nmol})$ or peptides $(10 \mathrm{nmol} /$ animal in $1 \mathrm{ml}$ saline) intravenously $1 \mathrm{~h}$ after intrathecal challenge with pneumococci as in Fig. 3. 10 control animals received PBS. Values represent mean \pm standard deviation of concentrations in CSF at $6 \mathrm{~h}$ after pneumococcal challenge ( $n \geq 4$ for peptide-treated animals; $n=4$ for FHA). * Statistically significant difference as compared with control at $P<0.02$.

of the integrin CD11b/CD18 (8). The present study provides evidence that the binding of a prokaryotic adhesive protein, FHA, to CD11b/CD18 mimics at least one binding loop of Factor X. FHA binds to cell-associated and purified CD11b/ CD18 $(13,14)$. Binding of FHA strongly inhibits subsequent binding of radiolabeled Factor $X$ to the activated integrin. This property appears to reside, at least in part, in the sequence ETKEVDG since this FHA peptide inhibited ${ }^{125}$ I-Factor X binding to stimulated neutrophils by $>80 \%$, while three other regions of FHA were less effective. This peptide resembles DTKQED, the Factor $X$ peptide which defines one binding loop for CD11b/CD18. The differences in the sequences ETKEVDG and DTKQED suggest that alteration of three residues in the Factor X peptide sequence does not influence the activities measured: aspartic acid to glutamic acid, glutamine to glutamic acid, and glutamic acid to valine. The fact that both FHA and Factor X peptides displayed activity suggests the importance of the conserved threonine, lysine, and aspartic acid or the spatial array of three acidic and one basic amino acid side chains.

The inhibition of binding of ${ }^{125} \mathrm{I}$ Factor $\mathrm{X}$ to leukocytes by the Factor X-derived peptide DTKQEDG was associated with a strong anticoagulant effect as measured by clotting time and generation of Factor Xa. The FHA peptide ETKEVDG showed a modest anticoagulant effect which was enhanced by acetyl/ amide modification of the peptide. Significant inhibition of coagulation was also characteristic of two other FHA peptides. Thus, three regions of FHA present sequence and functional similarity to binding loops of Factor X. To our knowledge, this is the first example of a bacterial peptide modulating the triggering of the coagulation cascade on the leukocyte surface.

It is of interest to note that another pathogen, Herpes simplex virus, encodes a Factor $\mathrm{X}$ receptor which recognizes the same three surface loops of Factor $\mathrm{X}$ as does CD11b/CD18 (8). It now appears that the converse situation also exists, i.e., a bacterium $B$. pertussis, displays Factor $\mathrm{X}$ homology regions that bind to native $\mathrm{CD} 11 \mathrm{~b} / \mathrm{CD} 18$ by sequences similar to native Factor $\mathrm{X}$. Given the importance of the CD11b/CD18-dependent entry 
of this pathogen into macrophages, this mimicry may provide an important mechanism to promote intracellular localization of the bacteria and thereby prolong the course of whooping cough. A predictable consequence of this binding is the inhibition of procoagulant activity. However, an additional effect of the FHA peptides, especially ETKEVDG, is to interfere with the ability of CD11b/CD18 to mediate binding and transmigration of leukocytes across endothelia. This unexpected effect and its relationship to activities of Factor $\mathrm{X}$ were dissected in more detail.

CD11b/CD18 promotes the firm adherence of neutrophils and monocytes to inflamed endothelia $(1,3,6)$. The effect of the binding of Factor $X$ to the integrin on its ability to participate in neutrophil transmigration has not been reported previously. We examined whether the Factor $\mathrm{X}$-peptides and FHA-peptides could block adherence and transendothelial migration of leukocytes. Native FHA and FHA peptides LGYQAK and ETKEVDG inhibited neutrophil adherence to activated cultured endothelial cells. LGYQAK was clearly more effective than the corresponding Factor X peptide, GLYQAK (42 vs $18 \%$, respectively); Factor $\mathrm{X}$-derived DTKQEDG was similar in inhibitory activity to FHA-derived ETKEVDG (38 vs $32 \%$, respectively). When peptides were tested for their ability to prevent migration of neutrophils across monolayers of activated endothelial cells, again LGYQAK and ETKEVDG were the most effective peptides ( $23 \pm 5$ and $21 \pm 10 \%$ inhibition, respectively) and showed greater inhibition than the related Factor $\mathrm{X}$ peptides ( $10 \pm 6$ and $14 \pm 9 \%$ inhibition). Activity of the ETKEVDG peptide was strikingly increased from 21 to $61 \%$ by introducing acetyl/amide modifications. This effect may arise from greater stability of the modified peptide (static plasma half-life prolonged from 4 to $>48 \mathrm{~h}$ ) (20), improved presentation of the relevant sequence to the integrin receptor, or sequestration of charge effects.

Several possible mechanisms underlying the effect of Factor $\mathrm{X}$-like peptides on CD18-mediated adherence of leukocytes were examined. The proteolytic activity of Factor $\mathrm{Xa}$ is unlikely to be involved since leupeptin did not affect leukocyte migration. In addition, strongly anticoagulant peptides (e.g., GLYQAKRFKVG) failed to block neutrophil adherence and migration. However, a formal elimination of this hypothesis will require development of Factor $\mathrm{X}$ with mutations ablating proteolytic action but not binding to cells.

Inhibition of leukocyte adherence to endothelium could also arise if the region of $\mathrm{CD} 1 \mathrm{lb} / \mathrm{CD} 18$ which binds endothelium was identical with or located near the Factor $\mathrm{X}$ binding site. This does not appear to be the case since Altieri has evidence that Factor $\mathrm{X}$ does not bind to the ICAM-1 binding domain of CD11b (Altieri, D. C., personal communication). Our observations also appear to be independent of ICAM-1 in that the peptides did not alter the inhibition of leukocyte adherence by IB4 which interferes with CD11b/CD18 binding to ICAM-1; rather, they were additive with IB4. Thus, it appears that Factor $\mathrm{X}$ influences adherence between leukocyte and endothelium by an interaction that is distinct from CD11b/CD18 binding to ICAM-1. These experiments do not distinguish if Factor $\mathrm{X}$ or its derivative, Factor $\mathrm{Xa}$, acts directly or indirectly on such an adhesion process.

The CD11b/CD18 adhesion molecule is an important target of strategies to develop antiinflammatory agents of therapeutic value. In the animal model of pneumococcal meningitis used here, leukocyte migration is strongly CD18 dependent (21). Intravenous injection of native FHA, the FHA peptides LGYQAK, ETKEVDG, acetyl/amide ETKEVDG, or the corresponding Factor X peptide GYDTKQEDG resulted in a $>70 \%$ reduction of leukocyte recruitment into the CSF at $7 \mathrm{~h}$ after intracisternal challenge with pneumococci. This effect is comparable with that achieved in this system by treatment with steroids $(21-23)$. To be of therapeutic significance, antiinflammatory agents must also prevent compromise of the barrier function of the cerebral capillary endothelium. ETKEVDG and its acetyl-amide derivative, the peptides most effective at inhibiting leukocyte migration, also effectively reduced influx of serum proteins into the CSF and accumulation of CSF lactate.

Currently, antiinflammatory therapy is recommended as an adjunct to antibiotics to decrease the morbidity and mortality of meningitis $(22,23)$. One such therapeutic candidate is an anti-CD18 antibody (21). The data presented here indicate for the first time that peptides are also viable therapeutic alternatives. Peptides have theoretical advantages in that they are more easily produced and are more amenable to multiple dose therapy as they are less antigenic. The precise mechanism of the in vitro and in vivo action of the peptides described here remains to be determined. However, the potential to deploy peptides which block both leukocyte transmigration as well as the coagulation cascade at sites of inflammation may afford added therapeutic advantage. The use of peptides patterned after regions of Factor $\mathrm{X}$ to reduce leukocyte accumulation in the CSF represents a novel antiinflammatory strategy.

\section{Acknowledgments}

We thank D. Altieri for advice on methods of measuring Factor X$\mathrm{CD} 11 \mathrm{~b} / \mathrm{CD} 18$ binding and for discussions as to the mechanism of the effects of the FHA peptides, T. Edgington for continued stimulating advice, Parul Parmar for technical assistance, and Tracy Olson for helpful discussions. Peptide synthesis was performed by the Protein Sequence Facility of The Rockefeller University supported by a Biomedical Research Support Grant Shared Instrumentation Grant from the National Institutes of Health.

This work was supported by National Institutes of Health grant 23459 (E. Tuomanen), the Swedish Institute (J. Straub), and Alkermes, Inc.

\section{References}

1. Harlan, J. M., P. D. Killen, F. M. Senecal, B. R. Schwartz, E. K. Yee, R. F. Taylor, P. G. Beatty, T. H. Price, and H. D. Ochs. 1985. The role of neutrophil membrane protein GP150 in neutrophil adherence to endothelium in vitro. Blood. 66:167-178.

2. Lawrence, M., and T. Springer. 1991. Leukocytes roll on a selectin at physiologic flow rates: distinction from and prerequisite for adherence through integrins. Cell. 65:859-873.

3. Lo, S. K., S. Lee, R. Ramos, R. Lobb, M. Rosa, R. G. Chi, and S. D. Wright. 1991. Endothelial-leukocyte adhesion molecule 1 stimulates the adhesive activity of leukocyte integrin CR3 (CD11b/CD18, Mac-1, alpha m beta 2) on human neutrophils. J. Exp. Med. 173:1493-1500.

4. Altieri, D. C., F. R. Agbanyo, J. Plescia, M. H. Ginsberg, T. S. Edgington, and E. F. Plow. 1990. A unique recognition site mediates the interaction of fibrinogen with the leukocyte integrin Mac-1 (CD11b/CD18). J. Biol. Chem. 265:12119-12122.

5. Altieri, D. C., and T. S. Edgington. 1988. The saturable high affinity association of factor $\mathrm{X}$ to ADP-stimulated monocytes defines a novel function of the Mac-1 receptor. J. Biol. Chem. 263:7007-7015.

6. Diamond, M., D. Staunton, A. de Fougerolles, S. Stacker, J. Garcia-Aguilar, M. Hibbs, and T. Springer. 1990. ICAM-1 (CD54). A counter-receptor for Mac1 (CD11b/CD18). J. Cell Biol. 111:3129-3135. 
7. Wright, S. D., P. E. Rao, W. C. Van Voorhis, L. S. Craigmyle, K. Iida, M. A. Talle, E. F. Westberg, G. Goldstein, and S. Silverstein. 1983. Identification of the C3bi receptor of human monocytes and macrophages by using monoclonal antibodies. Proc. Natl. Acad. Sci. USA. 80:5699-5703.

8. Altieri, D. C., O. R. Etingin, D. S. Fair, T. K. Brunk, J. E. Geltosky, D. P. Hajjar, and T. S. Edgington. 1991. Structurally homologous ligand binding of integrin Mac-1 and viral glycoprotein $\mathrm{C}$ receptors. Science (Wash. DC). 254:1200-1202.

9. Altieri, D. C., J. H. Morrissey, and T. S. Edgington. 1988. Adhesive receptor Mac-1 coordinates the activation of factor $\mathrm{X}$ on stimulated cells of monocytic and myeloid differentiation: an alternative initiation of the coagulation protease cascade. Proc. Natl. Acad. Sci. USA. 85:7462-7466.

10. Saukkonen, K., C. Cabellos, M. Burroughs, S. Prasad, and E. Tuomanen. 1991. The role of the interaction between Bordetella pertussis and macrophage integrin CR3 in pulmonary colonization. J. Exp. Med. 173:1143-1149.

11. Tuomanen, E., and A. Weiss. 1985. Characterization of two adhesins of Bordetella pertussis for human ciliated respiratory epithelial cells. J. Infect. Dis. 153:118-125.

12. Hoepelman, A. I. M., and E. I. Tuomanen. 1992. Consequences of microbial adherence: directing host cell functions with adhesins. Infect. Immun 60:1729-1733.

13. Van Strijp, J. A. G., D. G. Russell, E. Tuomanen, E. J. Brown, and S. D. Wright. 1993. Ligand specificity of purified complement receptor type 3: indirect effects of an Arg-Gly-Asp sequence. J. Immunol. 151:3324-3336.

14. Relman, D., E. Tuomanen, S. Falkow, D. T. Golenbock, K. Saukkonen, and S. D. Wright. 1990. Recognition of a bacterial adhesin by an eukaryotic integrin: CR3 (alpha $\mathrm{M}$ beta 2, CD11b/CD18) on human macrophages binds filamentous hemagglutinin of Bordetella pertussis. Cell. 61:1375-1382.

14a. Miletich, J. P., C. M. Jackson, and P. W. Majerus. 1978. Properties of the Factor Xa binding site on human platelets. J. Biol. Chem. 253:6908-6916.
15. Muller, W. A., and S. A. Weigl. 1992. Monocyte-selective transendothelial migration: dissection of the binding and transmigration phases by an in vitro assay. J. Exp. Med. 176:819-828.

16. Dacey, R., and M. A. Sande. 1974. Effect of probenecid on cerebrospinal fluid concentrations of penicillin and cephalosporin derivatives. Antimicrob. Agents Chemother. 6:437-441.

17. Tuomanen, E., H. Liu, B. Hengstler, O. Zak, and A. Tomasz. 1985. The induction of meningeal inflammation by components of the pneumococcal cell wall. J. Infect. Dis. 151:859-868.

18. Fung, M. R., C. W. Hay, and R. T. A. MacGillivray. 1985. Characterization of an almost full-length cDNA coding for human blood coagulation factor $\mathbf{X}$. Proc. Natl. Acad. Sci. USA. 82:3591-3595.

19. Relman, D. A., M. Domenighini, E. Tuomanen, R. Rapppuoli, and S. Falkow. 1989. Filamentous hemagglutinin of Bordetella pertussis: nucleotide sequence and crucial role in adherence. Proc. Natl. Acad. Sci. USA. 86:26372641.

20. Powell, M. F. 1993. Peptide stability in drug development: in vitro peptide degradation in plasma and serum. In Annual Reports in Medicinal Chemistry. J. Bristol, editor. Academic Press, Inc., San Diego, CA. 285-294.

21. Tuomanen, E., K. Saukkonen, S. Sande, C. Cioffe, and S. D. Wright. 1989. Reduction of inflammation, tissue damage, and mortality in bacterial meningitis in rabbits treated with monoclonal antibodies against adhesion-promoting receptors of leukocytes. J. Exp. Med. 170:959-969.

22. Odio, C. M., I. Faingezicht, M. Paris, M. Nassar, A. Baltodano, J. Rogers, J. Saez-Llorens, K. D. Olsen, and G. J. McCracken. 1991. The beneficial effects of early dexamethasone administration in infants and children with bacterial meningitis. N. Engl. J. Med. 324:1525-1531.

23. Quagliarello, V., and W. M. Scheld. 1992. Bacterial meningitis: pathogenesis, pathophysiology and progress. N. Engl. J. Med. 327:864-872. 